\title{
Analisa Perbandingan Penggunaan Citra Modis Level $1 b$ dan Level 2 dalam Menentukan Prakiraan Daerah Penangkapan Ikan (Studi Kasus: Pantai Selatan Blitar)
}

\author{
Eva Resti Febriani, Bangun Muljo Sukojo \\ Jurusan Teknik Geomatika, Fakultas Teknik Sipil dan Perencanaan, Institut Teknologi Sepuluh \\ Nopember (ITS) \\ Jl. Arief Rahman Hakim, Surabaya 60111, Indonesia \\ e-mail: bangunms@gmail.com
}

\begin{abstract}
Abstrak-Potensi sumber daya laut yang ada di Kabupaten Blitar untuk 4 mil laut mencapai 1.044 ton/tahun, untuk 12 mil Laut mencapai 3.133 ton/tahun dan Zona Ekonomi Ekslusif sebesar 52.220 ton/tahun. Dengan potensi yang besar dan pemanfaatan yang belum optimal diperlukan sebuah Peta Prakiraan Daerah Penangkapan Ikan untuk dapat memanfaatkan potensi sumber daya perikanan disana secara optimal. Penentuan prakiraan daerah penggunaan ikan dapat diprediksi dari parameter suhu permukaan laut dan klorofil-a. Analisa persebaran suhu permukaan laut dan klorofil-a dapat menggunakan Citra Modis Level 1b dan Level 2. Algoritma ATBD (Algoritm Theoretical Basic Document Modis) 25 untuk menentukan suhu permukaan laut dan Algoritma Morel 4 digunakan untuk menentukan klorofil-a. Hasil yang diperoleh dari penelitian ini adalah perbandingan Citra Modis level 1b dan 2 dengan menggunakan perhitungan uji RMSE. Dari kedua uji RMSE yang dilakukan antara data lapangan dengan data Citra Modis level 1b dan level 2 didapatkan nilai RMSE yang lebih bagus dan akurat didapat dari nilai penjumlahan RMSE yang paling kecil yaitu pada citra Modis Level 2 dengan nilai RMSE klorofil-a sebesar 0,090315 dan RMSE suhu permukaan laur sebesar 0,954544, jika dibandingan dengan nilai Uji RMSE suhu permukaan laut dan klorofil-a antara data lapangan dengan data Citra Modis level 1b. Jadi dalam menentukan prakiraan daerah penangkapan ikan yang paling baik adalah menggunakan Citra Modis Level 2.
\end{abstract}

Kata Kunci-Citra Modis, fishing ground, klorofil-a, suhu permukaan laut

\section{PENDAHULUAN}

$\mathrm{K}$ ABUPATEN Blitar potensi sumber daya laut yang ada di Kabupaten Blitar untuk 4 mil laut mencapai 1.044 ton/tahun, untuk 12 mil Laut mencapai 3.133 ton/tahun dan Zona Ekonomi Ekslusif sebesar 52.220 ton/tahun. Potensi ikan laut disana cukup menjanjikan, namun sampai sekarang pemanfaatan oleh nelayan Kabupaten Blitar atas potensi tersebut baru mencapai $10 \%$ dari potensi laut yang ada. Dengan potensi yang besar dan pemanfaatan yang belum optimal diperlukan sebuah Peta Prakiraan Daerah Penangkapan Ikan untuk dapat memanfaatkan potensi sumberdaya perikanan disana secara optimal.

Untuk mendukung upaya pengembangan perekonomian Indonesia dalam bidang kelautan, salah satu upaya yang dilakukan adalah pemanfaatan sumberdaya perikanan yang optimal. Pemanfaatan sumberdaya perikanan di indonesia kalah dengan negara tetangga yang memiliki luas lautan yang jauh lebih kecil dibanding indonesia. Dengan menggunakan teknologi penginderaan jauh atau remote sensing, saat ini kita telah dapat melakukan penglihatan pada cakupan wilayah yang sangat luas tanpa menyentuh benda tersebut dan dilakukan dengan waktu yang sangat singkat. Teknologi inilah yang dapat digunakan untuk menentukan posisi daerah potensi ikan. Sebaran klorofil-a dan suhu permukaan laut inilah yang merupakan indikator tingkat kesuburan perairan dan kelimpahan makanan bagi ikan. Salah satu instrumen yang dapat digunakan untuk mendeteksi keberadaan klorofil dan suhu permukaan laut yaitu citra satelit Modis.

Citra Modis memiliki 3 jenis data citra yaitu Citra Modis level 1a, 1b, 2, dan 3. Dalam penelitian ini kita menggunakan Citra Modis level $1 \mathrm{~b}$ dan level 2. Level 1 merupakan data mentah yang akan di proses menggunakan aloritma untuk memisahkan data-data yang terdapat pada Citra Aqua Modis. Level $1 \mathrm{~b}$ adalah data yang telah mempunyai terapannya, hasil dari kalibrasi sensor pada level 1a. Level 2 merupakan data citra gabungan dari data level $1 \mathrm{a}$ dan $1 \mathrm{~b}$. Level 2 merupakan data citra Aqua Modis yang telah terdapat proses algoritmanya, pada umumnya ahli-ahli oseonografi menggunakan data ini untuk penelitian yang akan dilakukan. Untuk melihat sebaran klorofil-a kita menggunakan algoritma MOREL 4 karena algoritma ini merupakan yang paling baik dari beberapa algoritma untuk mencari sebaran klorofil-a [1]. Sedangkan untuk melihat sebaran suhu permukaan laut kita menggunakan algoritma $A T B D \_25$.

\section{METODOLOGI PENELITIAN}

\section{A. Lokasi penelitian}

Lokasi penelitian Tugas Akhir ini mengambil daerah studi di perairan Pantai Selatan Blitar dan sekitarnya. Secara geografis terletak pada $8^{0} 15^{\prime} 0^{\prime \prime}-8^{0} 27^{\prime} 0^{\prime} \mathrm{LS}$ dan $112^{0} 0^{\prime} 0^{\prime}$ $112^{0} 15^{\prime} 0$ ' BT dalam penelitian berada pada posisi Gambar 1. 


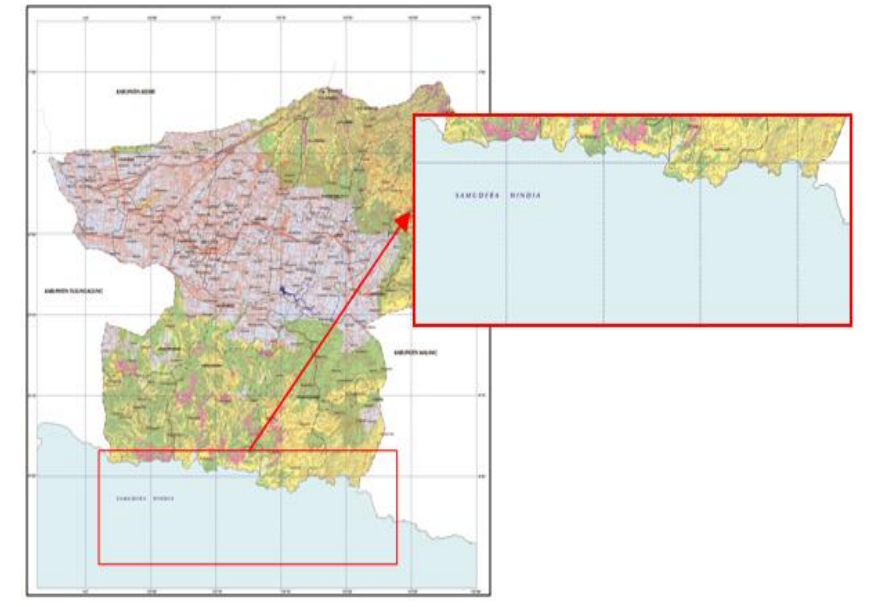

Gambar 1 Lokasi Daerah Penelitian (Sumber : Citra Modis Level 1b)

\section{B. Peralatan dan Data}

Data yang diperlukan dalam penelitian ini adalah:

1. Citra satelit Modis level $1 \mathrm{~b}$ dan Level 2 pada tanggal 19 April 2016.

2. Peta administrasi Indonesia skala 1:1.000.000 sebagai acuan dalam koreksi geometrik.

3. Data lapangan diambil secara in-situ di beberapa titik koleksi penelitian pada tanggal 20 April 2016.

Peralatan yang digunakan dalam penelitian ini meliputi:

1. Perangkat Keras (Hardware):

- Laptop

- GPS navigasi/handheld

- Thermometer Infrared

- Perahu motor, jam digital

2. Perangkat Lunak (Software):

- Sistem Operasi Windows 7

- Microsoft Word 2007

- Microsoft Excel 2007

- Microsoft Visio 2010

- Matlab R2010a

- $\quad$ ArcGIS 9.4

- ENVI 5.1

- Seadas 7.4

\section{Metode Penelitian}

Adapun tahap penelitian digambarkan secara umum dengan penjelasan sebaga iberikut:

1. Tahap Persiapan

\section{- Identifikasi Awal}

Bertujuan untuk mengidentifikasi permasalahan yang diangkat sebagai tema penelitian, objek penelitian dan daerah penelitian serta merumuskan cara memecahkan permasalahan tersebut. Adapun permasalahan dalam penelitian ini adalah bagaimana perbandingan penggunaan Citra Modis level 1b dan level 2 dalam menentukan prakiraan daerah penangkapan ikan di Pantai Selatan Blitar.

\section{- Studi Literatur}

Studi Literatur dilakukan untuk mempelajari dan mengumpulkan referensi dan hasil penelitian sejenis sebelumnya yang pernah dilakukan orang lain yang berkaitan sebagai dasar teori mengenai masalah yang akan diteliti suhu permukaan laut, klorofil, fishing ground, dan literatur lainnya yang mendukung baik dari buku, jurnal, majalah, internet dan lain sebagainya.

\section{- Pengumpulan Data}

Pengumpulan data berupa peta vektor Rupabumi Indonesia skala 1:1.000.000 dan data lapangan suhu permukaan laut dan klorofil-a.

2. Tahap Pengolahan Data

Pada tahapan ini dilakukan pengolahan dari data yang telah diperoleh dan data penunjang lainnya.

\section{Tahap Analisa}

Data yang telah diolah kemudian dianalisis sehingga di dapatkan suatu hasil yang perbandingan Citra Modis level 1b dan level 2 dalam menentukan prakiraan daerah penangkapan ikan.

4. Tahap Akhir

Penyusunan laporan merupakan tahap akhir dari proses penelitian ini sebagai laporan Tugas Akhir ini disertai dokumentasi dari pelaksanaan Tugas Akhir.

\section{Tahapan Pengolahan Data}

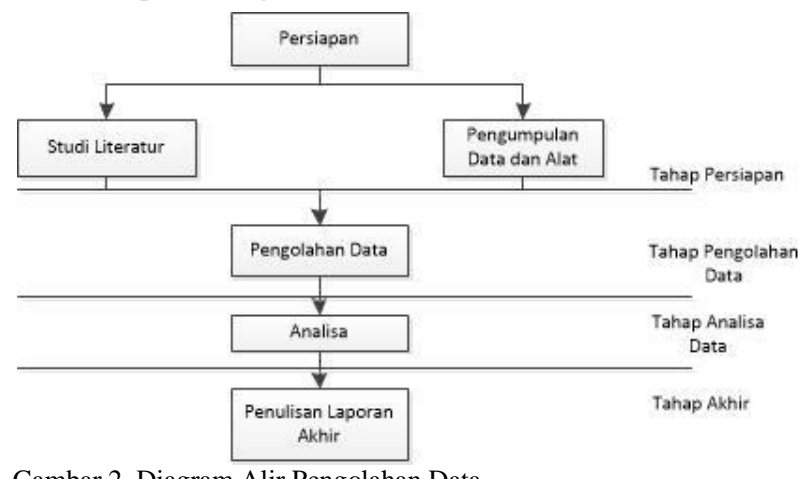

Gambar 2. Diagram Alir Pengolahan Data

\section{HASIL DAN ANALISA}

\section{A. Koreksi Geometrik dan SOF}

Dari koreksi geometrik yang dilakukan dengan menyebar titik-titik GCP diperoleh RMS error keseluruhan yaitu sebesar 0,417766 . Proses korekis geometrik pada citra ini sudah memenuhi toleransi batas kesalahan koreksi geometrik $\leq 1$ piksel.

Nilai strength of figure dari titik kontrol registrasi citra untuk setiap citra yang digunakan adalah sebesar 0,1532. Dalam hal ini semakin kecil bilangan faktor kekuatan jaringan tersebut, maka akan semakin baik konfigurasi jaringan yang bersangkutan.

Hasil RMS error mempunyai nilai kurang dari satu piksel dan $S o F$ mendekati nol sehingga dianggap memenuhi syarat yang diberikan. 


\section{B. Hasil Peta}

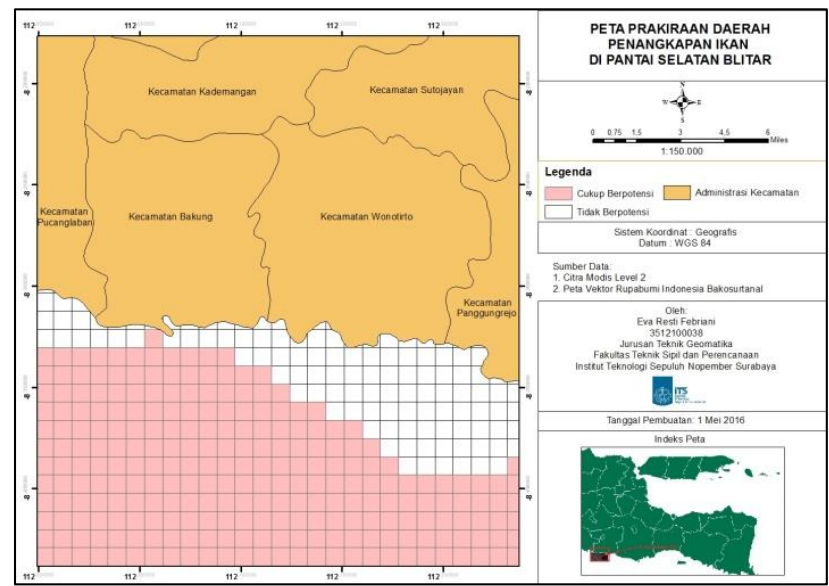

Gambar 3. Peta PDPI Menggunakan Modis Level 2

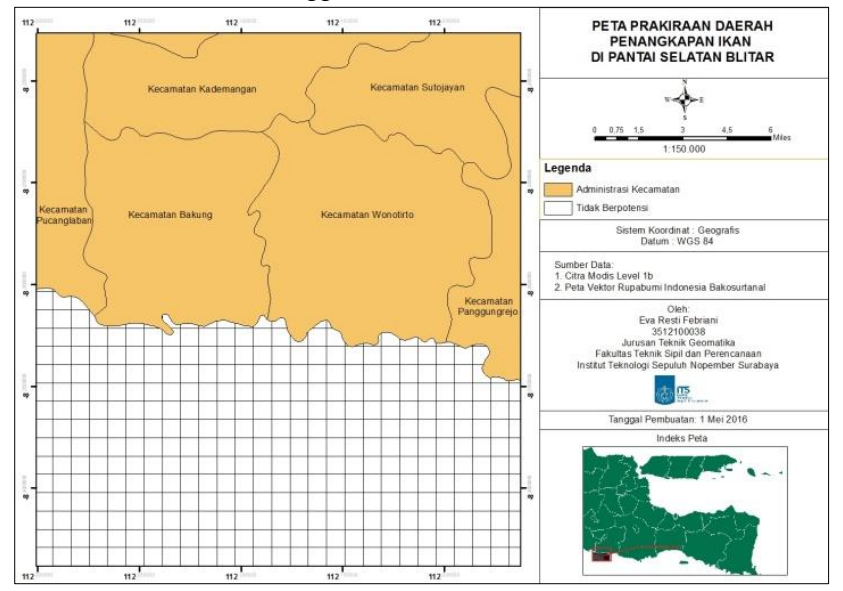

Gambar 4. Peta PDPI Menggunakan Modis Level 1b

\section{Analisa Data Lapangan}

Data lapangan yang telah didapatkan dinputkan pada citra yang terkoreksi geometrik, diperoleh data yang sesuai dengan piksel citra.

Tabel 1.

Data Lapangan

\begin{tabular}{ccccc}
\hline \multirow{2}{*}{ No } & \multicolumn{2}{c}{ Koordinat } & \multicolumn{2}{c}{ Data Lapangan } \\
& Bujur & Lintang & Klorofil-a $(\mathrm{mg} / \mathrm{l})$ & SPL $\left({ }^{\circ} \mathrm{C}\right)$ \\
\hline 1 & 112,15448610 & $-8,34657417$ & 0,174 & 29,6 \\
2 & 112,15591390 & $-8,35545556$ & 0,203 & 28,6 \\
3 & 112,14653060 & $-8,35405556$ & 0,145 & 29,6 \\
4 & 112,14653060 & $-8,35320556$ & 0,144 & 29 \\
5 & 112,13261110 & $-8,35235000$ & 0,232 & 28,9 \\
6 & 112,12334170 & $-8,35136111$ & 0,087 & 30,8 \\
7 & 112,11286110 & $-8,35102778$ & 0,23 & 29,6 \\
8 & 112,10230560 & $-8,34973056$ & 0,205 & 29,4 \\
9 & 112,10541110 & $-8,34581111$ & 0,21 & 29,4 \\
10 & 112,11424440 & $-8,33843056$ & 0,175 & 28,6 \\
\hline \hline
\end{tabular}

D. Analisa Area Fishing ground

Suhu permukaan laut, konsentrasi klorofil, arus laut, salinitas air laut, dan kandungan oksigen terlarut, fenomena upweeling dan front menjadi indikasi lokasi fishing ground, dimana daerah tersebut menandakan adanya fitoplankton yang merupakan makanan bagi ikan. Selain itu, terdapat juga faktor-faktor lain yang dapat mempengaruhi lokasi fishing ground ini. Dalam penelitian ini, untuk mencari atau menentukan suatu area fishing ground digunakan parameter sebaran klorofil-a dan juga suhu permukaan laut.

Dari pengolahan data yang dilakukan didapatkan hasil area fishing ground pada citra Modis level 1b dengan daerah semuanya tidak berpotensi. Sedangkan hasil area fishing ground pada citra Modis level 2 cukup berpotensi dengan luas $248 \mathrm{~km}^{2}$ dan sisanya adalah daerah cukup berpotensi.

\section{E. Analisa Perbandingan Citra Modis Level $1 b$ dan Level 2}

Untuk membandingankan citra modis level $1 \mathrm{~b}$ dan level 2 diperlukan suatu uji yang cocok karena dalam membandingkan citra tersebut didapatkan referensi data yang benar yaitu data lapangan (in situ). Uji yang digunakan dalam penelitian ini adalah uji RMSE. Uji RMSE merupakan salah uji yang digunakan untuk mencerminkan perbedaan antara data lapangan dengan data ekstraksi citra.

Dalam penelitiaan dilakukan uji RMSE klorofil-a dan suhu permukaan laut antara data lapangan dengan data Citra Modis Level $1 \mathrm{~b}$ dan Level 2. Dengan mendapatkan nilai RMSE dapat dilakukan perbandingan antara kedua data citra untuk mendapatkan hasil citra yang baik untuk digunakan dalam menentukan daerah prakiraan penangkapan ikan.

Tabel 2

Uji RMSE Klorofil-a antara Data Lapangan dengan Data Citra Modis Level $1 b$

\begin{tabular}{ccc}
\multicolumn{3}{c}{ Level 1b } \\
\hline \hline No & Data Citra $(\mathrm{mg} / \mathrm{l})$ & Data Lapangan $(\mathrm{mg} / \mathrm{l})$ \\
\hline 1 & 0,145 & 0,174 \\
2 & 0,140 & 0,203 \\
3 & 0,143 & 0,145 \\
4 & 0,145 & 0,144 \\
5 & 0,145 & 0,232 \\
6 & 0,146 & 0,087 \\
7 & 0,147 & 0,23 \\
8 & 0,147 & 0,205 \\
9 & 0,148 & 0,21 \\
10 & 0,146 & 0,175 \\
\hline \hline
\end{tabular}

Tabel 3

Uji RMSE Suhu Permukaan Laut antara Data Lapangan dengan Data Citra Modis Level 1b

\begin{tabular}{ccc}
\hline \hline No & Data Citra $\left({ }^{\circ} \mathrm{C}\right)$ & Data Lapangan $\left({ }^{\circ} \mathrm{C}\right)$ \\
\hline 1 & 28,134 & 29,6 \\
2 & 28,887 & 28,6 \\
3 & 29,731 & 29,6 \\
4 & 29,731 & 29 \\
5 & 29,883 & 28,9 \\
6 & 31,228 & 30,8 \\
7 & 30,732 & 29,6 \\
8 & 30,732 & 29,4 \\
9 & 30,732 & 29,4 \\
10 & 28,188 & 28,6 \\
\hline \hline
\end{tabular}

Dari data uji RMSE klorofil-a antara data lapangan dengan data citra Modis level $1 \mathrm{~b}$ menggunakan persamaan 5 didapatkan nilai RMSE sebesar 0,058502 dan uji RMSE suhu permukaan laut antara data lapangan dengan data cira modis level 1b sebesa 0,996001. Batas toleransi untuk nilai kesalahan RMSe adalah $\leq 1$ pixel, sehingga apabila nilai RMSe lebih besar dari 1 pixel (Purwandhi 2001) [2]. Muhsoni juga mengatakan bahwa semakin kecil nilai RMS error maka data yang didapat semakin bagus dan akurat [3]. Jadi uji RMSE klorofil-a dan suhu permukaan laut antara data lapangan dengan data citra Modis level $1 \mathrm{~b}$ memenuhi batas toleransi. 
Tabel 4

Uji RMSE Klorofil-a antara Data Lapangan dengan Data Citra Modis Level 2

\begin{tabular}{ccc}
\hline \hline No & Data Citra $(\mathrm{mg} / \mathrm{l})$ & Data Lapangan $(\mathrm{mg} / \mathrm{l})$ \\
\hline 1 & 0,041 & 0,174 \\
2 & 0,104 & 0,203 \\
3 & 0,150 & 0,145 \\
4 & 0,150 & 0,144 \\
5 & 0,199 & 0,232 \\
6 & 0,199 & 0,087 \\
7 & 0,334 & 0,23 \\
8 & 0,349 & 0,205 \\
9 & 0,213 & 0,21 \\
10 & 0,149 & 0,175 \\
\hline \hline
\end{tabular}

Tabel 5

Uji RMSE Suhu Permukaan Laut antara Data Lapangan dengan Data Citra Modis Level 2

\begin{tabular}{ccc}
\hline No & Data Citra $\left({ }^{\circ} \mathrm{C}\right)$ & Data Lapangan $\left({ }^{\circ} \mathrm{C}\right)$ \\
\hline 1 & 29,875 & 29,6 \\
2 & 30,070 & 28,6 \\
3 & 29,925 & 29,6 \\
4 & 29,925 & 29 \\
5 & 29,970 & 28,9 \\
6 & 29,970 & 30,8 \\
7 & 30,020 & 29,6 \\
8 & 30,020 & 29,4 \\
9 & 30,205 & 29,4 \\
10 & 30,000 & 28,6 \\
\hline \hline
\end{tabular}

Untuk uji RMSE klorofil-a antara data lapangan dengan data citra Modis level 2 didapatkan nilai RMSE sebesar 0,090315 dan uji RMSE suhu permukaan laut antara data lapangan dengan data cira modis level 2 sebesar 0,954544. Perhitungan uji RMSE menggunakan persamaan 5. Uji RMSE antara data lapangan dengan data citra Modis level 2 juga memenuhi batas toleransi sehingga kedua data tersebut dapat digunakan.

Dari kedua uji RMSE yang dilakukan antara data lapangan dengan data Citra Modis level $1 \mathrm{~b}$ dan level 2 didapatkan nilai RMSE yang lebih bagus dan akurat didapat dari pnilai penjumlahan RMSE yang paling kecil yaitu pada citra Modis Level 2 dengan nilai RMSE klorofil-a sebesar 0,090315 dan RMSE suhu permukaan laur sebesar 0,954544, jika dibandingan dengan nilai Uji RMSE suhu permukaan laut dan klorofil-a antara data lapangan dengan data Citra Modis level 1b. Jadi dalam penentukan prakiraan daerah penangkapan ikan yang paling baik adalah menggunakan Citra Modis Level 2.

\section{KESIMPULAN/RINGKASAN}

Berdasarkan hasil analisa penelitian ini yang telah di kemukakan, maka dapat diambil kesimpulan sebagai berikut :

- Dari pengolahan data yang dilakukan didapatkan hasil area fishing ground pada citra Modis level 1b dengan daerah semuanya tidak berpotensi. Sedangkan hasil area fishing ground pada citra Modis level 2 cukup berpotensi dengan luas $248 \mathrm{~km}^{2}$ dan sisanya adalah daerah cukup berpotensi.

- Dari kedua uji RMSE yang dilakukan antara data lapangan dengan data Citra Modis level $1 \mathrm{~b}$ dan level 2 didapatkan nilai RMSE yang lebih bagus dan akurat didapat dari nilai penjumlahan RMSE yang paling kecil yaitu pada citra Modis Level 2 dengan nilai RMSE klorofil-a sebesar 0,090315 dan RMSE suhu permukaan laur sebesar 0,954544, jika dibandingan dengan nilai Uji RMSE suhu permukaan laut dan klorofil-a antara data lapangan dengan data Citra Modis level 1b. Jadi dalam penentukan prakiraan daerah penangkapan ikan yang paling baik adalah menggunakan Citra Modis Level 2.

\section{DAFTAR PUSTAKA}

[1] Prasasti, Indah, Bambang Trisakti, dan Uyum Mardiana. "Sensitifitas Beberapa Algoritma dan Kanal-kanal Data Modis untuk Deteksi Sebaran Klorofil." Pertemuan Ilmiah MAPIN XIV "Pemanfaatan Efektif Penginderaan Jauh untuk Peningkatan Kesejahteraan Bangsa", September 2005: 113-122.

[2] Purwandhi, S H. Interpretasi Citra Digital. Jakarta: Grasindo, 2001.

[3] Muhsoni, F.F. Tutorial Pengolahan Citra Digital (Menggunakan ENVI). Bangkalan: Jurusan Ilmu Kelautan Fakuktas Pertanian Universitas Trunojoyo, 2008. 